And according this, the general theory of law formulates an anthropogenic interpretation of human dignity, the concept of which is defined as the self-worth of person as a unique biosocial being. In our opinion, these doctrinal positions in the near future will require appropriate legal and even constitutional regulation. Because the state must protect, defend rights and freedoms, guarantee their actual implementation. And also the state must create all the necessary conditions for decent work, provide social assistance to those who are in difficult life circumstances.

Key words: human and civil rights and freedoms, international human rights standards, classification of international human rights standards.

УДК 347.962 .3

DOI https://doi.org/10.32782/2409-4544/2020-1/8

В. Кравчук

\title{
Громадянські (особисті) права суддів як елемент їх конституційної правосуб'єктності
}

У статті досліджено права і свободи суддів, які втілюють сутність і зміст правового зв'язку судді з судами. Права суддів пропонується розглядати як вид і міру їх можливої або дозволеної поведінки, встановлені нормами права для реалізації їх функцій і завдань та забезпечуються державою. Автор вважає дискусійною позицію про те, що права суддів виникають виключно 3 моменту призначення на посаду судді. Деякі права (наприклад, право на повагу до гідності або право на результати творчої та інтелектуальної діяльності) належать громадянину і до призначення його на посаду судді, і після припинення суддівської діяльності. Однак після призначення на посаду судді вищевказані права набувають нового змісту і забезпечуються дещо іншими засобами державного примусу. У зв'язку з цим права суддів можна розділити на загальні і спеціальні. До загальних відносяться ті права, які належать судді як людині і громадянину, але після вступу у відповідний правовий статус змінюють зміст, порядок реалізації та забезпечення. До спеціальних належать права, які в науковій літературі прийнято називати посадовими, тобто пов'язані зі здійсненням правосуддя. Такі права виникають 3 моменту набуття особою правового статусу судді (з моменту складення присяги). Зазначені права можуть бути статусними (право на відставку, право на участь у суддівському самоврядуванні, право на повагу професійної честі та гідності тощо) та функціональними (право на витребування доказів, право на окрему думку тощо).

Ключові слова: суддя, правовий статус судді, права судді, конституційна правосуб’ єктність.

Постановка наукової проблеми та її значення. Будучи пов'язаним між собою численними юридичними зв'язками, права та свободи суддів становлять основу їх правового статусу. Для висвітлення прав і свобод суддів варто зупинитися на загальній характеристиці їх основних груп, виходячи із традиційної для вітчизняної юридичної науки класифікації на громадянські (особисті), політичні, економічні, соціальні, культурні та інші. При цьому особливу увагу заслуговують права судді, що належать йому як людині і громадянину, але в рамках статусу судді набувають особливого змісту.

Аналіз досліджень цієї проблеми. Поняття та зміст прав суддів були і залишаються предметом дослідження багатьох вітчизняних і зарубіжних вчених, зокрема В. Веніславського, В. Єгорової, В. Єфанової, О. Калашник, С. Лаптєва, Л. Москвич, О. Намясенко, С. Подкопаєва, С. Прилуцького, О. Скрипнюка, О. Совгирі, В. Федоренка, В. Шаповала, Ю. Шемшученка, Д. Шпенова, І. Шруб, Т. Штих, Н. Шукліної, Н. Шульгач та інших.

Мета даної статті полягає у розкритті громадянських (особистих) прав суддів як складового елемента їх конституційної правосуб' єктності.

Виклад основного матеріалу й обгрунтування отриманих результатів дослідження. Одним з перших громадянських (особистих) прав людини, що закріплене Конституцією України $\epsilon$ право на вільний розвиток своєї особистості. Дане право закріплене у Декларації про право на

(C) Крвчук В., 2020 
розвиток від 4 грудня 1986 року, відповідно до якої «право на розвиток є невід'ємним правом людини, володіючи яким кожна людина та усі народи мають право брати участь у такому економічному, соціальному, культурному та політичному розвитку, де можуть бути повністю здійснені всі права людини й основні свободи, а також сприяти йому та користуватися його благами» (ст. 1 ч. 1). Особливо важливим є положення Декларації про право на розвиток про те, що «людина $є$ основним суб' єктом процесу розвитку і повинна бути активним учасником та бенефіціарієм права на розвиток» (ст. 2 ч. 1) [1].

3 огляду на вищевказане, під правом на вільний розвиток особистості судді варто розуміти здатність використання суддею гарантованих Конституцією та законодавством правових можливостей для здійснення своїх інтересів задля реалізації внутрішнього потенціалу судді, як у повсякденному житті, так і при здійсненні правосуддя. Право суддів на вільний розвиток своєї особистості поєднує в собі властивості як негативних прав (наприклад, передбачає невтручання органів державної влади у здійснення суддями правосуддя), так і позитивних (тобто, вимагає створення державою необхідних умов для здійснення правосуддя).

Істотним громадянським (особистим) правом суддів є право на повагу до їх гідності. Як справедливо стверджує професор В. Федоренко «людська гідність є ключовою категорією сучасного конституціоналізму і квінтесенцією ідеї верховенства права» [2, с. 223]. На думку відомого дослідника Т. Р. С. Аллана: «Однакова гідність усіх громадян і справедливе ставлення й повага до індивідуальної автономії є базовими передумовами ліберального конституційного ладу і, відповідно, самою серцевиною принципу верховенства права» [3, с. 11]. Гідність суддів є їх невід'ємним внутрішнім ставленням до себе як до унікальних, цілісних особистостей, повноцінних членів суспільства. Як зазначає Л. Скомороха, судді, як особистості, притаманна загальнолюдська гідність, але ключову роль в цих рамках відіграє проекція правосуддя та судової влади на конкретного суддю. Ця проекція на особистість, що вже володіє набором позитивних рис, оцінених під час призначення їі на посаду судді, робить іiі людську гідність професійною. Тому гідність судді як сукупність його особистісних рис формує його лінію поведінки, одночасно є виразником гідності судової влади та спільноти суддів [4, с. 146].

Право суддів на повагу до їх гідності корелюється з міжнародними стандартами у галузі прав людини, закріпленими у ст. 5 Загальної декларації прав людини 1948 року, ст. 7 Міжнародного пакту про громадянські та політичні права 1966 року, Конвенції ООН проти катувань та інших жорстоких, нелюдських або таких, що принижують гідність, видів поводження і покарання 1984 року, ст. 3 Конвенції про захист прав людини та основоположних свобод 1950 року, Декларації про захист усіх осіб від катувань та інших жорстоких, нелюдських або таких, що принижують гідність, видів поводження чи покарання 1975 року, Свропейської конвенції про запобігання катуванням чи нелюдському або такому, що принижує гідність, поводженню чи покаранню 1987 року.

Право суддів на повагу до їх гідності отримало розвиток й у чинному законодавстві України. Наприклад, відповідно до ст. 129 ч. 5 Конституції України за неповагу до судді винні особи притягаються до юридичної відповідальності. Статтею 50 Закону України «Про судоустрій і статус суддів» встановлено, що прояв неповаги до судді з боку осіб, які є учасниками процесу або присутні в судовому засіданні, має наслідком відповідальність, установлену законом. Таким чином, держава гарантує захист честі суддів від будь-яких проявів неповаги.

Зокрема, ст. 185-3 Кодексу України про адміністративні правопорушення передбачена відповідальність за прояв неповаги до суду. Зазначена стаття Кодексу України про адміністративні правопорушення орієнтована на притягнення до відповідальності за неповагу до суду, а не безпосередньо до судді, хоча, очевидно і прояви неповаги до судді також можна вважати проявами неповаги до суду.

Більш конкретним в контексті захисту гідності судді та інших його прав є Кримінальний кодекс України. Так, у вісімнадцятому розділі Кримінального кодексу України передбачено відповідальність за наступні діяння, що свідчать про неповагу до гідності суддів: 1) втручання в будьякій формі в діяльність суддів 3 метою перешкодити виконанню ними службових обов'язків або добитися винесення неправосудного рішення; 2) погроза вбивством, насильством або знищенням чи пошкодженням майна щодо суддів, а також щодо їх близьких родичів у зв'язку з їх діяльністю, пов'язаною із здійсненням правосуддя; 3) умисне заподіяння суддям або їх близьким родичам побоїв, легких, середньої тяжкості або тяжких тілесних ушкоджень у зв'язку з їх діяльністю, пов'язаною із здійсненням правосуддя; 4) умисне знищення або пошкодження майна, що належить суддям або їх близьким родичам, у зв'язку з їх діяльністю, пов'язаною із здійсненням правосуддя; 5) посягання на життя суддів у зв'язку з їх діяльністю, пов'язаною із здійсненням правосуддя тощо. 
3 огляду на дану обставину видається правильною наукова позиція про виокремлення права на повагу професійної гідності судді. Крім цього, свого часу Л. Москвич пропонувала прийняти окремий закон, у якому був би наведений перелік дій, що можуть свідчити про неповагу до судді, а також встановлений порядок притягнення до відповідальності [5, с. 28]. Така пропозиція дещо дискусійна, оскільки встановити окремим законом, скажімо адміністративну відповідальність за неповагу до гідності судді можливо. А вже визначення складів злочинів, які стосуються неповаги до судді, та кримінальної відповідальності за них належить до сфери регулювання Кримінального кодексу України.

Іншим громадянським (особистим) правом $\epsilon$ право суддів на свободу та особисту недоторканність. Дане право закріплене міжнародним співтовариством у ст. 3 Загальної декларації прав людини 1948 року, ст. 9 Міжнародного пакту про громадянські та політичні права 1966 року, ст. 5 Конвенції про захист прав людини та основоположних свобод 1950 року та інших загальновизнаних міжнародних документах. Завдяки особистій свободі судді повною мірою можуть задовольняти власні потреби та інтереси, можуть розвивати і реалізовувати свої професійні здібності, здійснюючи правосуддя. Для цього важливо, аби особиста свобода суддів була гарантована і захищена від неправомірних посягань. На думку російського дослідника М. Клєандрова «недоторканність суддів $\epsilon$ не особистим привілеєм громадянина, котрий обіймає посаду судді, а засобом захисту публічних інтересів, передусім інтересів правосуддя. Варто також враховувати особливий режим роботи суддів, підвищений професійний ризик, наявність різних процесуальних та організаційних засобів контролю за законність дій та рішень суддів» [6, с. 64].

Право на недоторканність суддів гарантоване ст. 126 ч. 1 Конституції України. Також, відповідно до ст. 49 ч. 1 Закону України «Про судоустрій і статус суддів» суддя є недоторканним. Без згоди Вищої ради правосуддя суддю не може бути затримано або утримувано під вартою чи арештом до винесення обвинувального вироку суду, за винятком затримання судді під час або відразу ж після вчинення тяжкого або особливо тяжкого злочину. Крім того, суддю не може бути притягнуто до відповідальності за ухвалене ним судове рішення, за винятком вчинення злочину або дисциплінарного проступку.

Важливим громадянським (особистим) правом суддів є право на недоторканність житла. Дане право передбачає гарантовану державою охорону їхнього житла від незаконного вторгнення, проникнення та інших посягань з боку будь-яких суб'єктів правових відносин. Положення щодо недоторканності житла чи іншого володіння суддів означає не лише заборону входити до нього всупереч волі суддів, а й заборону розголошувати все, що в ньому діється. Недоторканними також $є$ й особисті речі, документи, кореспонденція, інші особисті папери та майно, що зберігаються у житлі чи іншому володінні суддів.

Відповідно до Постанови Пленуму Верховного Суду України № 2 від 28 березня 2008 року «Про деякі питання застосування судами України законодавства при дачі дозволів на тимчасове обмеження окремих конституційних прав і свобод людини і громадянина під час здійснення оперативно-розшукової діяльності, дізнання і досудового слідства» під житлом треба розуміти: 1) особистий будинок з усіма приміщеннями, які призначені для постійного чи тимчасового проживання в них, а також ті приміщення, які хоча й не призначені для постійного чи тимчасового проживання в них, але є складовою будинку; 2) будь-яке житлове приміщення, незалежно від форми власності, яке належить до житлового фонду і використовується для постійного або тимчасового проживання (будинок, квартира в будинку будь-якої форми власності, окрема кімната в квартирі тощо); 3) будьяке інше приміщення або забудова, які не належать до житлового фонду, але пристосовані для тимчасового проживання (дача, садовий будинок тощо) [7].

Спорідненим до права на недоторканність житла суддів є їх право на таємницю листування, телефонних розмов, телеграфної та іншої кореспонденції. Варто зауважити, що дане громадянське (особисте) право суддів не може бути зведене лише до забезпечення їх особистої та сімейної таємниці. Воно рівною мірою стосується і сфери їхніх професійних та ділових відносин. Порушення таємниці листування, телефонних розмов, телеграфної чи іншої кореспонденції, що передаються засобами зв'язку або через комп'ютер, тягне за собою кримінальну відповідальність, передбачену статтею 163 Кримінального кодексу України.

Право суддів на невтручання в їх особисте і сімейне життя, яке досить часто у вітчизняній правовій доктрині інтерпретується ще як право на недоторканність приватного життя (right to privacy). На думку В. Серьогіна «воно являє собою соціально зумовлену й гарантовану міру можливої поведінки особи, визначену нормами права, що має забезпечити автономію людини у сфері приватного життя для задоволення ï власних потреб та інтересів щодо усамітнення та приватного 
спілкування» $[8$, с. 153].

Особисте життя суддів гармонійно взаємодіє з їхньою професійною діяльністю. У цьому обидві форми соціального існування суддів $є$ неподільними. Однак, найбільш вразливим для можливих втручань $є$ особисте життя суддів. Власне, ст. 32 Основного Закону встановлює, що ніхто не може зазнавати втручання в його особисте і сімейне життя, крім випадків, передбачених Конституцією України.

Іншим громадянським (особистим) правом суддів $є$ право на свободу пересування, вільний вибір місця проживання та вільне залишення території України. Статтею 2 частиною 1 Протоколу № 4 до Конвенції про захист прав людини і основоположних свобод від 16 вересня 1963 року кожен, хто законно перебуває на території будь-якої держави, має право вільно пересуватися і вільно вибирати місце проживання в межах цієї території [9].

Право суддів на свободу думки і слова, на вільне вираження своїх поглядів і переконань передбачає, що усі судді мають невід'ємне право визначати для себе систему морально-етичних, світоглядних, духовних та інших ідей та ідеалів, а також вільно, без будь-якого ідеологічного чи іншого контролю оприлюднювати та обстоювати свої думки та погляди шляхом використання будьяких засобів їх вираження. Право суддів на свободу думки і слова, на вільне вираження своїх поглядів і переконань корелюється 3 правом вільно збирати, зберігати, використовувати i поширювати інформацію усно, письмово або в інший спосіб - на свій вибір (правом на інформацію).

Варто наголосити на окремих обмеженнях права суддів на свободу думки і слова, на вільне вираження своїх поглядів і переконань. Так, суддя не може робити публічних заяв, коментувати в засобах масової інформації справи, які перебувають у провадженні суду, та піддавати сумніву судові рішення, що набрали законної сили. Суддя не має права розголошувати інформацію, що стала йому відома у зв'язку з розглядом справи [10].

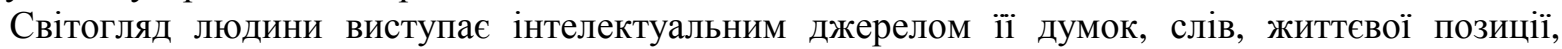
створюючи духовно-ідеологічний фундамент іï буття. Тож, світогляд судді впливає не лише на його особисте сприйняття оточуючої дійсності, але й на його професійну діяльність, трансформуючись у суддівську правосвідомість та знаходячи вираження у суддівському розсуді, про що йтиметься далі. Вірування як основа віросповідання, виступає невід'ємною складовою світогляду, адже існують явища оточуючого світу, що не знайшли наукового підтвердження. Різновидом реалізації свободи віросповідання є сповідування певної релігії. Тож, суддя, як і будь-який інший громадянин, може сповідувати будь-яку релігію або не сповідувати жодної, відправляти релігійні обряди, вести релігійну діяльність, за винятком обмежень, передбачених законом (наприклад, в інтересах охорони громадського порядку, здоров'я і моральності населення або захисту прав і свобод інших людей, як це передбачено ст. 35 ч. 2 Конституції України). Сповідування суддею будь-якої релігії або не сповідування ніякої також впливає на його світогляд, що пізніше може знаходити своє вираження, в тому числі у внутрішньому переконанні судді та прийнятих ним рішеннях.

Висновки. Отже, права суддів пропонуємо розглядати як вид i міру їх можливої чи дозволеної поведінки, що встановлені нормами права для реалізації їхніх функцій і завдань та забезпечувані державою. Права суддів, будучи важливим елементом їх правосуб' єктності, безсумнівно виступають вагомою складовою правового статусу суддів. Не можемо повністю погодитись 3 позицією, що права суддів виникають виключно 3 їх призначенням на посаду судді. Деякі права (наприклад, право на повагу до гідності, чи право на результати творчої та інтелектуальної діяльності) належать громадянину і до призначення його на посаду судді, і після припинення суддівської діяльності. Однак, після призначення на посаду судді вищевказані права набувають нового змісту та забезпечуються дещо іншими засобами державного примусу.

В зв'язку з цим права суддів можна поділити на загальні та спеціальні. До загальних можемо віднести власне ті права, які належать судді як людині і громадянину, але після набуття ним відповідного правового статусу змінюють зміст, порядок реалізації та забезпечення.

До спеціальних можемо віднести права, які в науковій літературі прийнято називати посадовими, тобто пов'язані зі здійсненням правосуддя. Такі права виникають 3 моменту набуття особою правового статусу судді (тобто, з моменту складення присяги). Зазначені права можуть бути статусними (право на відставку, право на участь у суддівському самоврядуванні, право на повагу професійної честі та гідності тощо) та функціональними (право на витребування доказів, право на окрему думку тощо). 
1. Декларація про право на розвиток, прийнята резолюцією 41/128 Генеральної Асамблеї від 4 грудня 1986 року [Електронний ресурс]. - Режим доступу: http://zakon3.rada.gov.ua/laws/show/995_301.

2. Федоренко В. Л. Конституційне право України: підручник / В. Л. Федоренко. -К.: Вид-во Ліра-К, 2016. - $616 \mathrm{c}$.

3. Аллан Т. Р. С. Конституційна справедливість. Ліберальна теорія верховенства права / Т. Р. С. Аллан; пер. з англ. Р. Семківа. - К.: Вид. дім «Києво-Могилянська академія», 2008. - 385 с.

4. Скомороха Л. Окремі аспекти посади професійного судді / Л. Скомороха // Право України. - 2016. - № 8. - C. 140-149.

5. Москвич Л. М. Правовий статус носіїв судової влади в Україні (професійні судді, народні засідеталі, суд присяжних: монографія) / Л. М. Москвич, С. О. Іваницький, І. О. Русанова; за заг. ред. I. С. Марочкіна. - Харків: Фінн, 2009. - 488 с.

6. Клеандров М. И. Статус судьи: учебное пособие / М. И. Клеандров. - Новосибирск: Наука; Сибирская издательская фирма РАН, 2000. - 444 с.

7. Про деякі питання застосування судами України законодавства при дачі дозволів на тимчасове обмеження окремих конституційних прав і свобод людини і громадянина під час здійснення оперативно-розшукової діяльності, дізнання і досудового слідства: Постанова Пленуму Верховного Суду України № 2 від 28 березня 2008 року. [Електронний ресурс]. - Режим доступу: http://www.scourt.gov.ua/clients/vsu/vsu.nsf/(documents)/60C6115C9EF459C0C2257AF4005219 BA.

8. Серьогін В. О. Право на недоторканність приватного життя у конституційно-правовій теорії та практиці: монографія / В. О. Серьогін. - Х.: ФІНН, 2010. - 453 с.

9. Протокол № 4 до Конвенції про захист прав людини і основоположних свобод, який гарантує деякі права і свободи, не передбачені в Конвенції та у Першому протоколі до неї від 16 вересня 1963 року. [Електронний ресурс]. - Режим доступу: http://zakon5.rada.gov.ua/laws/show/994_059

10. Кодекс суддівської етики, затверджений XI черговим з'їздом суддів України 22 лютого 2013 року [Електронний ресурс]. - Режим доступу:https://court.gov.ua/userfiles/Kodex\%20sud\%20etiki(1).pdf.

Кравчук В. Гражданские (личные) права судей как элемент их конституционной правосубъектности. В статье исследованы права и свободы судей, которые воплощают сущность и содержание правовой связи судьи с судами. Права судей предлагается рассматривать как вид и меру их возможного или дозволенного поведения, установленные нормами права для реализации их функций и задач и обеспечиваемые государством. Автор считает дискуссионной позицию о том, что права судей возникают исключительно с момента назначения на должность судьи. Некоторые права (например, право на уважение достоинства или право на результаты творческой и интеллектуальной деятельности) принадлежат гражданину и до назначения его на должность судьи, и после прекращения судейской деятельности. Однако после назначения на должность судьи вышеуказанные права приобретают новый смысл и обеспечиваются несколько иными средствами государственного принуждения. В связи с этим права судей можно разделить на общие и специальные. К общим относятся те права, которые принадлежат судье как человеку и гражданину, но после вступления в соответствующий правововой статус меняют содержание, порядок реализации и обеспечения. К специальным относятся права, которые в научной литературе принято называть должностными, то есть связанные с осуществлением правосудия. Такие права возникают с момента приобретения лицом правового статуса судьи (с момента принесения присяги). Указанные права могут быть статусными (право на отставку, право на участие в судейском самоуправлении, право на уважение профессиональной чести и достоинства и т.д.) и функциональными (право на истребование доказательств, право на особое мнение и т.д.).

Ключевые слова: судья, правовой статус судьи, права судьи, конституционная правосубъектность.

Kravchuk V. Civil (Personal) Rights of Judges as a Feature of Their Constitutional Legal Personality. The article examines the rights and freedoms of judges, which embody the essence and content of the legal relationship of judges with the courts. The author suggests considering the rights of judges as a type and measure of their possible or permissible behavior, which is established by law for the implementation of their functions and tasks and provided by the state. The author believes controversial the position that the judge's rights arise only at the moment when a person is appointed as a judge. Some rights 
(for example, the right to respect dignity or the right to the results of creative and intellectual activity) belong to a citizen before his appointment as a judge and after his judicial activity termination. However, after the appointment to the position of a judge, the above rights acquire a new meaning and are secured by somewhat other means of state coercion. In this regard, the rights of judges can be divided into general and special. The general rights include those rights that the judge enjoys as a person and a citizen, but after acquiring the appropriate legal status, they change the content, procedure for implementation, and the way of their provision. Special rights include the rights, which are called official rights in the scientific literature, ie they are related to the administration of justice. Such rights arise from the moment a person acquires the legal status of a judge (in other words, from the moment of taking the oath). These rights can be status (the right to resign, the right to participate in judicial self-government, the right to respect for professional honor and dignity, etc.) and functional (the right to demand evidence, the right to a dissenting opinion, etc.).

Key words: judge, legal status of a judge, rights of a judge, constitutional legal personality. 